present at the interview, were of the opinion that the child could hear and understand very simple sentences. She was said to have difficulty in expressing herself, owing to her Turkish-speaking background. Her intelligence and emotional stability were said to be at least average, and her adjustment at school appeared very satisfactory. Auriscopy showed the lef drum to be normal, and the right drum retracted. Calling the child by name, with her eyes closed, or while standing behind her, on either side, produced the impression that she did not respond to or localize sounds in either ear.

Some days later the headmistress mentioned that on a previous day she had repeatedly called after the child, who was going home from school, and the child had remained unaware of her. This was the first time that any member of the teaching staff had suspected deafness during the six months in which the child was at school

The mother later attended for interview, and was accompanied by an English-speaking Turkish Cypriot friend. Deafness was said to have been first suspected by both parents at the age of years, when there was no progress in speech development. It was said that the child's speech, even in Turkish, was very restricted.

The child was later tested at a special audiology unit and it was clear from the audiogram that she had a high frequency loss of hearing, with a fairly severe superimposed conductive loss.

The child was recommended for a school for deaf children, and some months later was seen to be using headphones, with an amplifier, for school lessons, and was using hearing-aids at other times. She had fitted in well at the school and was making some progress despite the language difficulty.

It is unusual to see a child with bilatera undetected deafness at the age of 8 years The diagnosis at this age may be overlooked because of the assumption that the condition would have been discovered earlier.

It was initially thought that the Turkishspeaking background of the child, and not deafness, was the cause of lack of comprehension of speech. In addition, the high intelligence of the child had enabled her to develop the art of lip reading and of interpreting facial expression.

I would like to thank Dr. L. Fisch, consultant otologist, for his help with this child.

-I am, etc.,

London S.W.3.

J. J. TROY.

\section{Scared to Death ?}

SIR,_-I read with interest the account of the woman reported by Dr. Elkington and his colleagues ( 7 August, p. 363) who accurately forecast her own death at the age of 43 . However, one is left wondering why. a fortuneteller should impart such devastating information to so young a child which was to make such a terrible and lasting impression upon her.

Her case reminded me of the instances of " angor animi" which were reported in this journal last year, ${ }^{1-3}$ though in these patients awareness of "impending dissolution" was of a much shorter duration.

I well remember seeing another patient in 1952 in his early 40's, who I have little doubt had some foreknowledge of his imminent demise. On admission to hospital he was extremely agitated, overbreathing excessively, and appeared to be suffering from cardiac asthma. There was no significant previous medical history. He was sitting up in bed all the time struggling for breath, clutching on to me and another doctor shouting,
"Doctor, doctor, I am going to die, I am going to die, please don't let me die, please don't let me die, please, please. ..." $\mathrm{He}$ repeated this over and over again and caused much commotion in the ward. With grea difficulty we administered oxygen and intravenous aminophylline, but perhaps mistakenly withheld morphine, fearing that this might depress his respiration. Thereafter we just stood back and watched him helplessly while he cried out. Suddenly he stopped and slumped down in the bed. He was dead half an hour after admission. Curiously, a most careful necropsy revealed no abnormalities whatsoever and there was no evidence of pulmonary oedema. We were all of the opinion that he had died of fright.

It would be interesting to know much more about the personality of Dr. Elkington' patient, perhaps from relatives or friends, and about the nature of her anxiety during the preceding three years; also whether she was often depressed or had ever made a suicidal attempt. Furthermore, it is possible that were she a hysterical manipulative type her psychological symptoms, stress incontinence and reaction to it, leading to surgery and its attendant complications, might have resulted from her own unconscious efforts to predetermine her demise at the appointed time, having reflected endlessly upon the admonitions of her soothsayer. Hysterical mechanisms of this kind are not uncommon and have been lucidly elaborated by Menninger, ${ }^{4}$ particularly in patients who undergo repeated operations (" polysurgery," " polysurgical addiction," "Munchausen syndrome "). 5 Such patients may readily transfer responsibility for their own actions on to another party, the surgeon, who may thereby be unwittingly and quite easily drawn into the patient's scheme of things.

Nevertheless, the problems presented by this patient and which occupy the fringe territory of medicine and psychiatry are of considerable scientific interest, and much more research is needed. Perhaps the boundaries of western psychiatry should now begin to be extended to include some of the phenomena of extra-sensory perception ?-I am, etc.,

\section{Shelton Hospital,
Shrewsbury, Shropshire.}

J. C. BARKER.

\section{REFERENCES}

1 Barker, J. C., Brit. med. 7., 1964, 2, 688

Morrison, J.' M., ibid., 1964, 2, 949.

Woolich, J. G., ibid., 1964, 2, 1141 . Part IV, p. 259.' Rupert Hart-Davis, London. Asher, R., Lancet, 1951, 1, 339

- Barker, J. C., f. ment. Sci., 1962, 108, 167

SIR,-I was very interested to read the letter under the above heading ( 7 August, $p$ 363). The case may represent a version of voodoo death. Voodoo-like suggestion caused the development of a previously non-existent and eventually fatal episode. The suggestion implanted into the patient's mind at the age of 5 that she would die when she was 43 triggered off the mechanism of her postoperative collapse.

A number of observers in independen reports ${ }^{1}$ gathered from various parts of the world admit that there are instances indica ting that the belief that one has been subjected to spells of sorcery, and in consequence is inevitably condemned to death, does actually result in death in the course of time. This phenomenon is characteristically noted among the primitive human beings. Some, however, believe that it may exist in our cultured society. A persistent state of fear can end the life of man. Fear is one of the most deeply rooted and dominant emotions. Associated with it are profound physiological disturbances, widespread throughout the organism.

One of these is the overaction of the sympathetic nervous system, which exercises control over the internal organs and also the bloodvessels. If the state of perturbation due to fear continues uncontrolled for a considerable period very serious results may ensue. There is a gradual fall in the blood-pressure towards the end, which is due to a reduction of the volume of the circulating blood. Deterioration, therefore, occurs in the heart and also in the nerve centres, which held the blood-vessels in moderate contraction. The very organs which are necessary for the maintenance of an adequate circulation are damaged. The gradual reduction of the blood volume is due to the action of the sympathetic nervous system in causing a persistent constriction of the small arterioles. The very thin walls of the capillaries are sensitive to oxygen want, and become more and more permeable to the fluid part of the blood. The plasma therefore escapes into the perivascular spaces. The loss of fluid excites the sympathetic nervous system; thus a vicious circle is set up. A state of shock is produced by the continuous outpouring of adrenaline characterized by a rapid pulse and haemoconcentration. The heart is beating faster and faster, finally getting into a state of constant contraction and death in systole. The post-mortem examinations in such cases usually reveal nothing definite which could account for the fatal outcome.

A case of death from a voodoo-like sugges tion was reported by Mathis. ${ }^{2}$ A man aged 53 , in a civilized community, developed as a result of a voodoo-like suggestion a previously non-existent and eventually fatal illness. It was unfortunate that in the "Labrador" case the fear of the patient was not known at the time of the operation. Fear expressed by a patient about the result of an operation is a reason why some surgeons would refuse to operate. ${ }^{3}$ A suggestion implanted into a human mind can persist for many years. It has been found that some post-hypnotic suggestions can last effectively for many years. If the suggestion of "Death at 43 " could have been removed by counter-suggestion before the operation, the fatal issue could have been avoided.

"Scared to Death" is not an idle saying. A feeling "I am afraid I am going to die" may actually result in death. The anxiety is not removed even when the patient is anaesthetized. Although asleep, the patient is still suffering from anxiety. - I am, etc.,

London S.E.25.

A. FrY.

\section{REPERENCES}

1 Cannon, W. B., Psychosom. Med., 1957, 19, 182. 2
3 Finney, J. M.' T., Ann. Surg., 1934, $100,746$.

\section{"Early, Curable Stage" of Rheumatoid Arthritis}

SIR,-It was not my intention to instruct Dr. John W. Todd how to treat the "early curable stage of rheumatoid arthritis," but to point out that a great deal can be done now to mitigate the crippling effects of arthritis.

In his second letter (24 July, p. 234) Dr. Todd challenges me with "What is the proper advice?" to the patient and his doctor. 